\title{
The use of concessions for overcoming crisis and pre-emergency condition of housing-and- communal facilities
}

\author{
Natalia Levoshich ${ }^{1}$ and Alina Fatkullina ${ }^{2.3^{*}}$ \\ ${ }^{1}$ Financial University under the government of the Russian Federation, 125993, Leningrad pr.49, \\ Moscow, Russia \\ ${ }^{2}$ Moscow State University of Civil Engineering, 129337, 26 Yaroslavskoye sh., Moscow, Russia \\ ${ }^{3}$ Moscow architectural institute, 107031,11/4, Rozhdestvenka Street, Moscow, Russia
}

\begin{abstract}
The purpose of the article is to develop some recommendations on the improvement of housing-and-communal services financing on the basis of the mechanism of public-and-private partnership, and namely on the basis of concessionary agreements. The analysis of the housing-andmunicipal industry condition was carried out with the use of the municipal infrastructure development index. According to the analysis results, the that a considerable part of housing-and-communal facilities are in crisis or pre-emergency condition. It is fraught with technogenic accidents, damage to an environment, additional expenses on compensation of the environmental damage. Besides, the ecological costs of outdated and wornout facilities are high even without emergence of accidents. The conclusion was drawn that development, repair and replacement of worn-out objects of housing-and-communal infrastructure are necessary. In turn, additional financing of the sphere is necessary for this purpose. The experience of the concessionary agreements implementation in the Russian regions is considered. The conclusion is drawn that this experience positive in general, but the mechanism also has some shortcomings, some problems of the legislative regulation exist. Further distribution of concessions demands purposeful measures. The corresponding recommendations, developed by the author of the article, can be useful for regional and municipal authorities as well as for specialists of the companies, working in the field of housing-and-public services.
\end{abstract}

\section{Introduction}

Housing-and-communal services play one of the most important roles in society's life. This sphere provides people with favorable conditions for their accommodation, maintaining stability of the whole society, satisfying the needs of people for housing-and-communal services.

\footnotetext{
* Corresponding author: doptaganka@yandex.ru
} 
However, the majority of the housing-and-communal facilities are in crisis or preemergency condition. Besides, the undeveloped complex of municipal housing-andcommunal facilities is not the main issue, concerning the state. The resource potential and consumption, their stock in the territory of the city and in the country in general is the priority matter. And the deficiency of non-renewable resources is known to be one of the global problems of the world [1].

However, this problem can be solved by the means of additional investments attraction. Therefore, the search of their sources is a relevant task of modern management.

Works by such scientists as A.A. Abolin, V.R. Avanesyan, S.V. Barulin, L.P. Badilin, A.M. Mantises, V.A. Nefedov, S.B. Sivayev, V.M. Talalykin, Rudy L.Yu., Klyuev I.S., Zhundrikov A. are devoted to the solution of this task $[2,3,4]$

The author of this research believes that concessions can become an effective funding mechanism for the housing-and-public services development.

There is certain experience in this direction in Russia. The National Public-and-Private Partnership Center operates; the Fund of assistance to the housing sector reforming is organized for support of concession projects, the appropriate branch of legislation is created.

However, concessions are widespread in the sphere of housing-and-public services still insufficiently, and that causes the necessity of further research and development of some recommendations.

\section{Materials and Methods}

Systems analysis, statistical, datalogical, program and target methods were used within the research.

Materials of Federal State Statistics Service, technical-and-economic and financial performance of activity of the enterprises and the housing-and-communal facilities, were studied during the research.

The analysis of the need and expediency of the use of concessions in the field of housing-and-public services was preceded by the analysis of the industry development index [5].

When calculating the industry index for housing-and-communal services the following parameters were considered:

- the provision of the population of regions with sources of heat and water supply and also with water sewage services;

- the share of the well-planned dwelling stock, that is the stock, provided with all the main types of facilities;

- the emergency rate and decay of housing.

The legislation acts were studied as the legal base of the research:

- Law No. 115-FZ "On concessionary agreements",

- Order by the Government of the Russian Federation No. 673, November 11, 2006 "On the approval of the standard concessionary agreement concerning facilities for production, transfer and distribution of electrical and heat energy",

- Order by the Government of the Russian Federation No. 748, December 5, 2006 "On the approval of the standard concessionary agreement concerning the systems of municipal infrastructure and other objects of municipal services, including facilities of water- heat-, gazo- and power- supply, water sewage, sewage treatment, processing and utilization of household wastes, the facilities, intended for lighting of territories of residential and rural settlements, the facilities, intended for the improvement of territories and also facilities of social purposes". 


\section{Results}

The average municipal infrastructure development index for the country makes 6.91 in 2019. The position of the industry concerning other infrastructure spheres has been strengthened a little. Rather high rate is the consequence of bigger prevalence and ubiquity of municipal facilities. So, water supply, sewerage and heat supply exist in all the regions.

The value of the industry index in the municipal sphere grew in 55 regions, did not change in 7 regions, and decreased in the rest 23 regions.

Murmansk region holds the leadership according to the municipal infrastructure development (8.27). That can be connected with a high share of urban population. St. Petersburg holds the second place. North Ossetia (8.01) have managed to overtake Moscow (7.91). Statistically North Ossetia has lower values of accident rate for housing and higher share of the houses provided with all the types of improvement, than the capital has, while the municipal capacities per person are developed approximately equally.

Municipal infrastructure is developed in the federal districts quite evenly. And the highest average rate for the district (7.09) is fixed according the results of 2019 in the Central Federal District, Ural Federal District and North Caucasus federal district at the same time.

But 42 regions have values infrastructure development index below the average level over the country while there were 41 such regions a year ago. Vladimir region joined the regions, conditionally lagging behind. (Figure 1).

Table 1. Distribution of the municipal infrastructure development index throughout the country and federal districts

\begin{tabular}{|l|c|c|}
\hline \multicolumn{1}{|c|}{ Regions } & $\mathbf{2 0 1 8}$ & $\mathbf{2 0 1 9}$ \\
\hline Russia & 6.89 & 6.91 \\
\hline Central Federal District & 7.0 & 7.09 \\
\hline Northwestern Federal District & 6.99 & 6.99 \\
\hline Southern Federal District & 6.93 & 6.93 \\
\hline North Caucasian Federal District & 7.02 & 7.02 \\
\hline Volga Federal District & 6.95 & 6.99 \\
\hline Ural Federal District & 7.03 & 7.09 \\
\hline Siberian Federal District & 6.51 & 6.51 \\
\hline Far Eastern Federal District & 6.56 & 6.55 \\
\hline Murmansk region & 8.25 & 8.27 \\
\hline Moscow & 7.97 & 7.91 \\
\hline Murmansk region & 8.25 & 8.27 \\
\hline Astrakhan region & 7.47 & 7.46 \\
\hline North Ossetia & 7.96 & 8.01 \\
\hline Krasnoyarsk Krai & 7.23 & 7.26 \\
\hline Samara region & 7.61 & 7.65 \\
\hline Yamalo-Nenets Autonomous Area & 7.54 & 7.72 \\
\hline Chukotka Autonomous Okrug & 7.38 & 7.34 \\
\hline Tuva & 5.50 & 5.47 \\
\hline Kostroma region & 6.34 & 6.33 \\
\hline Vologda region & 6.16 & 6.15 \\
\hline Kalmykia & 6.39 & 6.39 \\
\hline Dagestan & 5.57 & 5.61 \\
\hline Kirov region & 6.34 & 6.36 \\
\hline Kurgan region & 6.14 & 6.15 \\
\hline Yakutia & 5.79 & 5.71 \\
\hline
\end{tabular}


The most difficult situation with the municipal infrastructure is observed in Dagestan (5.61), Altai Republic (5.59) and Tuva (5.47).

According to Ministry of Construction and industry experts, the situation in housingand-communal services worsens year by year: the wear and extent of the networks demanding replacement grow. For example, according to the Ministry, just the need of heat supply for investments for the facilities modernization makes 300 billion rubles a year.

There is no reason to wait for an inflow of funds in the nearest future: tariffs are much lower than the level, which is necessary to meet such requirements.

One of solutions is the implementation of municipal projects with the use of the concession mechanism at the level of the regional and municipal authorities [6].

Experience proves that upon the private investor joining the reliability of the industry increases. So, the emergency rate decreased by $47 \%$, energy losses decreased by $18 \%$ at the facilities of heat supply, transferred to the concessionaire.

Now more than 2.5 thousand similar concessions are concluded in Russia, but their mostly do not belong to the qualified market segment.

Only 48 subjects have more or less acquired concession experience in the municipal sphere if to estimate the segment of projects, investment into which are more than 100 million rubles. However, the number of such municipal concessions is a little more than 160 items (without the sphere of municipal solid waste) has no significant effect on the infrastructure of the industry in general, and can change it only locally.

As a rule, the concession mechanism is used in large municipalities where the investor has the wide field of activity, and growth of tariffs, inevitable because of the increase in costs for modernization, can be divided among a bigger number of consumers.

However, the research proved, that sometimes it is possible to transfer small municipal services to private management effectively.

So, in the Kotovsk monotown, Tambov region the concessionary agreement on the modernization of the heating system has been implemented since 2016, six block and modular boiler houses, which provide 95 percent of apartments with heat, were put into maintenance there. Half a billion rubles was spent on the project implementation: 300 million was given by Fund of assistance to reforming of housing-and-communal facilities, 200 million was invested by the Compulink company. The investor has to update all the city heating systems during three years. The tariff for the population would grow by 50 percent without any federal support.

One more scheme of public-and-private partnership for housing-and-communal services, i.e. energy service contracts, was successfully tested in Tambov region. Municipalities sign contracts with "AAA Engineering" Joint Stock Company, which replaces old street lamps with energy saving lamps. At the same time the expenses on lighting are cut down. The guarantee for the new equipment is seven years long, during this period the contractor undertakes to serve and change the lamps free of charge. The energy service contract is the only form of public-and-private partnership, at which the project is implemented only at the expense of the investor without joint financing from regional and local budgets. At the same time costs are compensated due to the economy of means, reached thanks to the introduction of energy-saving technologies.

An energy power service contract on modernization of the heating ssytem system of Solnyshko kindergarten was signed in the industrial settlement of Znamenka of the Tambov region. The pilot investment project will cost 2.1 million rubles. The investor, the Moscow company "Ektiv Sotsenergoservice", undertakes to establish individual heating point with weather regulation in the kindergarten and also to provide its guarantee maintenance for seven years. Upon the contract termination the equipment will be transferred to the customer in good repair. According to the specialists' estimates, the economic effect of the 
innovation will be 52 percent, and the economy on the facility heating will be more than 560 thousand rubles a year.

According to the results of the half year 2019 the total investment in municipal concessions, which are more expensive than 100 million rubles, about 270 billion rubles, and the sphere of heat supply takes 74 billion rubles. That is the investments in it through concessions for several years do not cover even $25 \%$ of annually required means.

However, the conducted research proves that the capacity of the municipal industry still remains incompletely opened even in the large segment of concession projects (more expensive than 1 billion rubles). For example, concession on the water supply and water sewage facility of the Belgorod region on which a tender was cancelled at the beginning of August, assumed investments of 10 billion rubles. However, the start of such projects can be limited to strong dependence on a tariff and experience of the concessor, whose experience is very often not enough.

It is necessary to emphasize some measures for the increase in the housing-andcommunal services efficiency and for attraction of concessions $[7,8]$ :

1. The increase in funds of non-residential premises and their delivery in lease. The trend of growth of housing stock is distinctly shown; that can be considered as a positive trend $[2,3,5]$. The fund of non-residential premises means increases too. Thus, the company increases working areas, used for the new municipal facilities placement; that is attractive to investors as they have more opportunity for the implementation of housingand-communal projects.

2. Special attention to repair work in the specialized companies. This method will allow to improve working conditions in the companies, delivering housing-and-communal services; that promotes the improvement of labour productivity and helps to attract a great amount of investments for further implementation of new projects.

3. Creation of dispatching services for maintenance of technical equipment in residential buildings. Housing sector can be one of the most attractive branches of the economy for concessionaires, however, nowadays this industry acts as the counter party owing to inefficiency of the existing managerial system. The current crisis state of the industry is caused by the dependence on subsidies in this sphere, deficiency of funds for its restoration and updating, high costs, backwardness of the competition, and as a result inefficient work of the enterprises. Consolidation of dispatching services on service of residential buildings will allow to increase the quality, volume and speed of work. That will lead to better attraction of concessions.

4. Implementation of new technologies. Modern information technologies (IT) allow to keep account of consumption warm-, water-and energy- resources, to watch the condition of facilities, to provide interaction between suppliers and consumers of resources. The quality and reliability of information is the most valuable resource, demanded by all the market participants. IT will help investors to calculate the necessary investments and expected return, reducing their costs at the same time. Introduction of IT will allow final consumers of housing-and-communal services to control the consumed resources and to optimize their expenses.

\section{Discussion}

According to the federal law No. 115-FZ "On concessionary agreements", approved on 21.07.2005, the agreement is signed not by two parties (the concessor and the concessionaire), but by three. The territorial subject of the Russian Federation participates as the independent party of the concessionary agreement without fail. The head of the supreme executive body of the government of the territorial subject of the Russian Federation acts on behalf of this party. In case of not signing of the concessionary 
agreement by the territorial subject of the Russian Federation (which subject are heat supply facilities, centralized systems of hot water supply, cold water supply and (or) water sewage, separate facilities of such systems) such concessionary agreement is considered unconcluded

Actually, the law just "appointed" the territorial subject of the Russian Federation the third party in the agreement, without having settled the matters of its participation in the competitive procedures and the order of signing of such agreement subsequently. Cases when the subject has the right to refuse signing, as well as the cases when it is obliged to sign the agreement are not concretized $[9,10]$.

Terms are very important in the spheres of water supply, heat supply. The quicker an enterprise (in most cases small Ltd companies, created somehow to service the networks in small settlements) will be included into full work, the quicker it will get all the necessary permissions and documents, including tariffs [11]. The situation take place, when the third party, having absolutely indirect relation to the agreements, actually can block such agreements at discretion .

Today the territorial subject of the Russian Federation, being quite a narrow participant of the concessionary agreement, can express the remarks and disagreement only concerning that part of the agreement which concerns directly its rights and duties. It can control the agreement realization only in the part concerning it.

According to some experts, this gap needs elimination. Until it is made the authorities of the region have an uncontrollable opportunity to interfere with the maintenance of the facilities of the water supply system and heating systems. The author do not relieve responsibility for low quality of work from the municipalities, but it neccessary to consider the volume of the heritage they got (the lack of any documents on the facilities of water supply and water sewage, their condition). The state actually kept from the solution of a real problem once again, and the concessionary agreements, hardly concluded earlier, in fact stopped and its destiny became uncertain.

\section{Conclusions}

Thus, the analysis of the municipal infrastructure development index proved that the situation at housing-and-communal facilities crisis. The sphere has a great need of investments and concessions could bring the considerable benefit in it.

Considering the relevance of concessionary agreements application, we can name the following external factors:

- Active development of the housing-and-communal facilities infrastructure;

- Reduction of the budgetary expense on raw projects;

- Reduction of the business role because of the market relations development;

- Overcoming the high level of housing-and-municipal facilities wear.

Despite the unprofitable condition of the housing-and-communal services as the sector of the economy, it should be noted that private investors are interested in the municipal industry. First of all, it is connected with the following reasons:

1. The housing-and-communal services are the vital and necessary market, therefore, demand for it will be always guaranteed. That will certainly attract investors.

2. The enterprises, providing housing-and-communal services act as monopolists to some extent;

3. Paying services, the population creates the stable, predicted, timely payments for the enterprise.

The implemented concession projects in housing-and-communal sphere gave positive results. It is possible to name some benefits of concessionary agreements for the state 
- the opportunity to improve (reconstruct, modernize) housing-and-communal facilities, without spending budgetary funds;

- the property, transferred to private traders for the temporary use, nevertheless continues to be the municipal or state-owned property;

- partnership leaves the right to watch managing of private investors and to control the process.

The disadvantage of the concession mechanism is that it is difficult to find an investor, who would be ready to invest huge amounts, the representatives of small business or the former municipal unitary enterprises which do not have sufficient finance express their desire to make a concession partnership most often.

The vector of the concessionaires' efforts has to concentrate on the housing-andcommunal facilities in medium-sized settlements (up to 250 thousand inhabitants).

Some measures, including application of information technologies and further improvement of the legislation are necessary for the further development of the concession mechanism in the sphere.

\section{References}

1. National association of concessionaires and long-term investors in the infrastructure, Long-term institutional investments in the infrastructure of Russia on the basis of concession: results of 2018 [Digital resource] Access mode: https://investinfra.ru/uploads/file/2019/yLLJ-VhZZNXJWuZY.pdf

2. I.S. Klyueva, Housing-and-public facilities as the component of the social infrastructure, in book Modern problems of economy and finance. (Novosibirsk, 2013).

3. L.Yu. Rudi, I.S. Klyueva, Quality of housing stock as the characteristic of housing conditions of the Novosibirsk region population: some trends, in book Quality and usefulness in the economic theory and practice (Novosibirsk, NSUEM Publishing house, 2016).

4. I.S. Klyueva, L.Yu. Rudi, The housing system of the post-industrial society, or what housing system is formed in Russia, in book Evolution of state policy in the context of modern neoindustrial development of Russia (Novosibirsk: NGASU (Sibstrin) Publishing house, 2014).

5. J. Delmon, Understanding options for private participation in infrastructure: Seeing the forest for the trees: PPP, PSP, DBFO, concession, lease... (World Bank, 2010)

6. E. Vasilyeva, A. Mottaeva, E3S Web of Conferences, 91, 08051, (2019) doi.org/10.1051/e3sconf /20199108051

7. E. Vasilyeva, I. Polyakova, MATEC Web of Conferences, 106, 08097 (2017) https://doi.org/10.1051/matecconf/201710608097

8. A.Gassner, E. Popov, K. Pushak, Does the Private Sector Deliver on its Promises? Evidence from a global study in water and electricity distribution (World Bank, 2007)

9. A. Mottaeva, N. Kalinina , A. Kuzmina, O. Olenina and A. Glashev, E3S Web of Conferences, 91,08072, (2019) doi.org/10.1051/e3sconf /20199108072

10. Strategy of housing and communal services development in the Russian Federation till 2035 [Digital resource] Access mode: http://gorodsreda.ru/proekt-zhkkh/
11. A. Mottaeva, E3S Web of Conferences, 110, 02164 https://doi.org/10.1051/e3sconf /2019(11011002164 